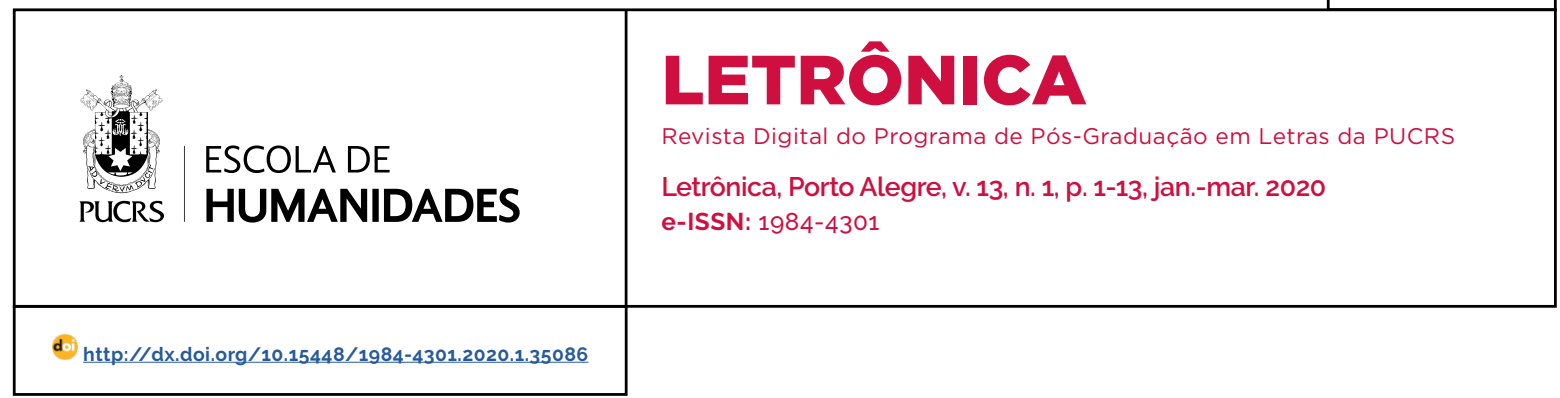

\title{
As filhas dos homens e os espelhos: o olhar feminino em romances de Raquel de Queiroz e Lygia Fagundes Telles
}

\author{
The men's daughters and the mirrors: the female perspectives \\ in novels of Rachel de Queiroz and Lygia Fagundes Telles \\ Las hijas de los hombres y los espejos: la perspectiva femenina \\ en novelas de Rachel de Queiroz y Lygia Fagundes Telles
}

\author{
Marilia Garcia Boldorini ${ }^{1}$ \\ orcid.org/0000-0002-0748-4680 \\ mariliaboldorini@gmail.com
}

\section{Roberta Barros Meira ${ }^{1}$}

orcid.org/0000-0001-7739-216X rbmeira@gmail.com

Recebido em: 28 jul. 2019. Aprovado em: 29 nov. 2019. Publicado em: 7 abr. 2020.

\section{(c) (7)}

Artigo está licenciado sob forma de uma licença Creative Commons Atribuição 4.0 Internacional.
Resumo: Rachel de Queiroz e Lygia Fagundes Telles despontaram na literatura brasileira não só por conta do seu talento literário, mas sobretudo por serem mulheres em um cenário predominantemente masculino e por darem voz a personagens femininas fortes em meio a uma educação conservadora. Em suas obras, ambas as autoras de certa forma denunciaram os problemas de uma geração de mulheres limitada por valores sociais arraigados na cultura patriarcal e cristã ao longo do século XX. O paralelo entre os livros As três Marias, de Queiroz (1939), e As meninas, de Telles (1973), aqui presente deixa essa questão muito clara. Por intermédio da comparação entre os dois textos, discutem-se neste artigo pontos como o papel social e a liberdade sexual da mulher nessa sistemática, além da emancipação feminina e da convivência com a pressão das convenções sociais e com as parcas opções de vida a que tinham acesso principalmente na primeira metade do século $X X$, debatendo paradigmas sob o viés da diversidade social e da perspectiva feminina. Palavras-chave: Literatura brasileira. Rachel de Queiroz. Lygia Fagundes Telles.

Abstract: Rachel de Queiroz and Lygia Fagundes Telles appeared in the Brazilian literature not just because their literary talent, but mainly for being women in a scene predominantly male and for giving voice to female and strong characters in a conservative education context. In their books, both the authors in a certain way have reported the problems of a generation of women who were limited by social values rooted in a patriarchal and Christian culture over the XX century. The parallel drawn here between As três Marias, by Queiroz (1939), and As meninas, by Telles (1973), clarifies this point. Through the comparison between the two texts, we discuss in this article questions as the social role and sexual liberation of women in this system, beyond the female emancipation, the pressure of social conventions and the few life options that women had access especially in the first half of the XX century, debating paradigms under the social diversity and the female perspective. Keywords: Brazilian literature. Rachel de Queiroz. Lygia Fagundes Telles.

Resumen: Rachel de Queiroz y Lygia Fagundes Telles despuntaran en la literatura brasileña no solamente en razón de su talento literario, pero sobre todo por ser mujeres en un escenario predominantemente masculino y por dar voz a personajes femeninos fuertes en medio a una educación conservadora. En sus obras, las dos autoras de cierta manera denunciaran los problemas de una generación de mujeres restringida por valores sociales arraigados en la cultura patriarcal y cristiana al largo del siglo XX. El paralelo entre los libros As três Marias, de Queiroz (1939), y As meninas, de Telles (1973), aqui presente deja esa cuestión muy clara. Por intermedio de la comparación entre los dos textos, se discuten en este artículo puntos como el papel social y la libertad sexual de las mujeres en esa sistemática, además de la emancipación femenina y de la convivencia con la presión de las convenciones sociales y con las exiguas opciones de vida a que tenian acceso principalmente en la primera mitad del siglo XX, debatiendo paradigmas por el punto de vista de la diversidad social y de la perspectiva femenina. Palabras clave: Literatura brasileña. Rachel de Queiroz. Lygia Fagundes Telles. 


\section{Introdução}

Ao longo da história, verifica-se que a literatura sempre foi predominantemente masculina, muito em função de as mulheres, de maneira especial as de familias mais pobres, não terem acesso à educação, o que engloba a linguagem escrita. Portanto, não sabendo nem ler nem escrever, cabiam às mulheres de familias mais abastadas basicamente as tarefas domésticas e o cuidado dos filhos, enquanto as mulheres de classes sociais inferiores eram de grande valia para a sobrevivência das familias e na provisão do lar, já que participavam ativamente do mercado de trabalho, em função da precariedade das condições sociais, não tendo tempo, por conseguinte, à educação formal. De qualquer forma, acessar os bancos escolares era uma realidade distante. As mulheres tiveram, porém, papel crucial na difusão de valores religiosos e, na mesma corrente, culturais, perpetuados pela Igreja, um dos poucos lugares constantemente frequentados por elas.

Pertencentes a uma narrativa literária e historiográfica que reforçou uma visão marcada por estereótipos, as figuras femininas constituiram um contar que trazia forte percepção de imobilidade, sacrificio, religiosidade extrema, submissão sexual, reclusão, ou a imagem recorrente de uma mulher mestiça lasciva. Nesses escritos científicos, religiosos ou literários, o papel de mãe era comumente contraposto à imagem das mulheres que destoavam do modelo ideal, ou seja, adúlteras, prostitutas e feiticeiras.

Nas últimas décadas, a historiografia vem buscando investigar uma história das mulheres que não é homogênea ou pacifica, mas que carrega no seu bojo conflitos e resistências. Nesse sentido, buscou-se ressignificar as fontes primárias tradicionais e os romances pelos espaços pouco estudados ou "sombreados", conforme expressão de Hardman (1988), da imbricada atuação de identificação e resistência aos ditames de uma sociedade com bases patriarcais. Essa investigação, como comprova Mary Del Priore (1994, p. 59), faz emergir sujeitos históricos que, ao fugir dos enquadramentos "entre Maria e Eva", permitem que se chegue hoje a uma complexidade de vidas possiveis que enriquecem uma história do Brasil ao abarcar uma leitura complexa dos mundos femininos.

O aumento do número de textos atuais que quebram o silenciamento ou trazem as mulheres como sujeitos da história permite constatar novas demandas e investigações, muitas vezes em intima relação com um passado de invisibilidade na literatura, em discursos nas esferas políticas e acadêmicas, nos livros escolares, nos jornais etc. Embora faça sentido dizer que a literatura e a história contam com uma quantidade expressiva de imagens e discursos sobre as mulheres registradas ou escritas por homens, podemos imaginar que grande parte desses registros trazem as maneiras que o ciclo de vida das mulheres foi observado e ressignificado pelos homens.

Nesse caso, como bem coloca Michelle Perrot (2007, p. 31), para "ouvir suas vozes - as palavras das mulheres, é preciso abrir não somente os livros que falam delas, os romances que contam sobre elas [...], mas também aqueles que elas escreveram". Como guardiãs de suas próprias memórias, os casos de escritos de mulheres como Raquel de Queiroz e Lygia Fagundes Telles são narrativas instigantes que permitem reescrever e desafiar o status quo da literatura e da história. Nesse sentido, essas obras demonstram a possibilidade de se avançar em um cenário no qual a falta de equilibrio de gênero segue sendo uma questão ainda hoje, tanto no que se refere à autoria quanto a personagens.

Os autores que mais sobressaem hoje em dia, de acordo com as listas dos mais vendidos, continuam sendo homens, os quais, em sua maioria, ainda descrevem nas páginas de suas obras as mulheres como o sexo frágil e em busca do seu grande amor, retratando que a visão masculina (talvez a da sociedade como um todo) perante a mulher sofreu poucas alterações através dos tempos, propagando um conceito estereotipado e romantizado do feminino no mundo. Segundo dados de uma pesquisa feita pela Universidade de Brasilia (UnB), citada por Costa (2017), nas grandes editoras mais de 70\% das publicações são escritas por homens, o 
que revela a escassez de vozes femininas no mercado editorial. Além disso, 60\% das histórias são protagonizadas por homens, dos quais $80 \%$ são brancos e 90\% heterossexuais. A mesma pesquisa mostra que 90\% das obras literárias foram escritas por brancos, denunciando também a disparidade racial, além de a metade dos autores ser de origem do eixo Rio de JaneiroSão Paulo. O interessante é observar que essa investigação abrange os anos entre 1964 e 2014. um período bastante próximo ao momento atual.

Portanto, se ainda hoje se veem questões como desigualdade racial e de gênero no mercado editorial e nos demais âmbitos sociais igualmente, são surpreendentes os feitos da escritora Rachel de Queiroz na literatura e também em torno de todo o contexto sociopolítico e cultural da época em que viveu, sobretudo em prol da equidade de gênero, embora ela mesma não reconhecesse tais atos como a favor desse movimento. Nordestina, mulher e do começo do século XX, nascida em 1910, ela desafiou as convenções sociais e apostou no seu talento para a escrita, revelando condições de submissão e conformidade no que tange à geração de mulheres com que conviveu e da qual fazia parte.

A primeira mulher a ocupar uma cadeira na Academia Brasileira de Letras (ABL), em 1977. apesar de a instituição existir desde 1897, mesmo não se identificando com o movimento feminista, Rachel de Queiroz transformou-se, ao se tornar imortal e pelo conjunto de sua obra literária, em um icone na luta por equidade entre os gêneros. Todos os seus livros dão voz a personagens femininas fortes e discutem a realidade nordestina, em um paralelo entre as origens da própria autora, em uma corrente de certa maneira contrária ao que a literatura brasileira em geral explora. Cearense de Fortaleza, Rachel de Queiroz versa sobre o universo íntimo de mulheres mediante as questões politicas, sociais e culturais do Brasil do século XX.

Entre as suas várias obras, todas voltadas para a temática de gênero, indicando uma literatura engajada, As três Marias, originalmente publicado em 1939, foi o livro escolhido para ser discutido neste artigo. Trata-se de um romance autobiográfico que abrange temas sociais importantes, além da autonomia e da liberdade femininas. A narrativa discorre sobre as experiências vividas pelas personagens desde a infância, quando se conheceram, em um internato de freiras, perpassando pela juventude, até chegar à vida adulta, com todos os dilemas e as preocupações de se enquadrar em uma sociedade claramente repressora e engessada, principalmente no que se refere às mulheres.

De modo a levantar alguns pontos que formam a base do romance de Rachel de Queiroz e que permanecem em constante debate ainda na atualidade, no século XXI, envolvendo sobretudo o universo feminino e o contexto em que essas questões aparecem, pensou-se em traçar aqui um paralelo entre a obra As três Marias e o livro As meninas, de Lygia Fagundes Telles. Embora este se passe em outro momento e espaço, um pouco mais próximo dos dias de hoje, contudo ainda no século $X X$, seu cerne fundamenta-se essencialmente em três jovens que dividem suas experiências da juventude em um pensionato religioso, tal qual se deu no livro de Rachel de Queiroz, vivenciando cada uma a sua história, demonstrando unidade e individualidade, mas ao mesmo tempo a convivência com a pressão das convenções sociais e com as parcas opções de vida a que as mulheres têm acesso.

Além dessas semelhanças no que tange às publicações escolhidas para discussão, a literatura da paulistana Lygia Fagundes Telles, embora um pouco mais recente, entretanto, assim como a da autora cearense, também é considerada visionária, ao questionar paradigmas sob o viés da diversidade social e da perspectiva feminina, colocando personagens mulheres como protagonistas de suas obras e donas do seu próprio destino. Em 2016 Lygia Fagundes Telles foi indicada a concorrer ao Prêmio Nobel de Literatura - ocasião em que Bob Dylan levou o prêmio -, tamanho o seu mérito literário. Foi a primeira mulher brasileira a integrar a disputa. Mais um feito inédito para as mulheres. Ela foi ganhadora, porém, repetindo o feito de Rachel de Queiroz, do Prêmio Camões, distinção maior em língua portuguesa pelo conjunto da obra. 
Assim, por todo o trabalho literário e pelas demonstrações de engajamento social dessas autoras, é fundamental abordá-las no meio acadêmico e também na mídia em geral, apesar de ser perceptível o sombreamento de ambas perante o grande público, que acaba prendendose aos cânones literários, clássicos da literatura escritos por homens, discutindo pontos que, em alguns casos, já foram exaustivamente tratados.

\section{As imagens refletidas por duas mulheres}

É impossivel abordar o tema literatura feminina sem mencionar o feminismo², ou o quanto as mulheres ficaram culturalmente à margem em razão do sistema patriarcal, modelo social que ainda hoje prevalece em todo o mundo.

Considera-se relevante apontar que a dificuldade de se fazer uma história das mulheres perpassa por um modelo de exclusão. As estatísticas e os documentos oficiais trazem dados na sua grande maioria assexuados. Ademais, os espaços e as práticas femininos são constantemente pensados como sem importância. Isso nos indica, porém, o quão significativo é um novo olhar menos petrificado sobre fontes que podem deslindar os espaços de poder patriarcais e os movimentos de resistência. Segundo a avaliação de Perrot (2005, p. 13), a literatura seria uma das fontes mais ricas, por conter "esta epopeia do coração e da família". Ou seja, deixa evidente o cotidiano ao revelar informações como o grau de alfabetização, as redes de solidariedade, a religiosidade e os saberes que passam por uma grande variedade de conhecimentos, como a música, a medicina, a culinária, a administração. Posteriormente, o contar dessas lutas femininas ganharia cada vez mais espaço para a apropriação de outros campos de comunicação, como o jornalismo, a história e a presença marcante na literatura, seja na poesia, seja no romance.

Em seu artigo, Duarte (2003) traça um panorama da literatura no Brasil pelo viés feminista e explica que no início do século XIX as mulheres ainda viviam enclausuradas na rigidez cultural que impunha a elas a limitação doméstica. Deu-se somente em 1827 a abertura, por meio de legislação específica, de escolas públicas femininas, as quais eram esparsas e voltadas aos ensinamentos da religião católica. Quando a familia era mais abastada, contudo, havia a opção de escolas particulares, ou o ensino individualizado. De qualquer forma, todas essas instituições ocupavam-se apenas com as prendas domésticas, a fim de preparar as mulheres a um bom e próspero casamento.

Assim, cabia às mulheres que tinham a oportunidade de aprender a ler e a escrever tentar mudar um pouco o rumo das coisas, assumindo um protagonismo ainda inédito na sociedade brasileira.

E foram aquelas primeiras (e poucas) mulheres que tiveram uma educação diferenciada, que tomaram para si a tarefa de estender as benesses do conhecimento às demais companheiras, e abriram escolas, publicaram livros, enfrentaram a opinião corrente que dizia que mulher não necessitava saber ler nem escrever (DUARTE, 2003, p. 153).

Enfrentando preconceitos, olhares tortos e todo tipo de desconfiança, tais mulheres avançavam na literatura e já no começo do século XX fundaram jornais e revistas claramente feministas e que duraram por bastante tempo, sobretudo na capital do Brasil à época, o Rio de Janeiro, e em outros pontos do país, a fim de discutir os direitos femininos, como, por exemplo, o direito ao voto, à igualdade, à educação e ao mercado de trabalho. Esses periódicos, explica Duarte (2003), funcionaram como mola propulsora para a expansão da condição social feminina, por meio de uma rede de apoio mútuo e do intercâmbio cultural, configurando-se como ferramenta indispensável para a conscientização e emancipação femininas. Resistências ainda existiam, mas tratou-se de um importante passo para o que viria a seguir.

\footnotetext{
2 O movimento feminista sofre bastante resistência e preconceito no Brasil, tendo sido associado erroneamente a mulheres mal-amadas e que não são femininas. A escritora nigeriana Adichie (2012) vê na palavra feminista certo peso negativo e reforça que tem a impressão de que a ideia de feminismo é limitada por estereótipos, ou seja, feministas "são mulheres infelizes que não conseguem arranjar marido" (ADICHIE, [2012]). Todavia, o movimento feminista é legitimo e ocorre no mundo todo, sendo o responsável por conquistar inúmeros direitos às mulheres, como o direito ao voto, a frequentar a universidade e a dirigir (DUARTE, 2013), apesar de ainda ter-se muito o que alcançar.
} 
Embora não se reconhecesse como integrante do movimento feminista, Rachel de Queiroz é facilmente identificável com essas mulheres, por conta de sua história de vida e da sua literatura engajada no que diz respeito ao mundo feminino, além de seus livros terem sido de grande auxilio à abertura do mercado editorial às mulheres. Nascida no ano de 1910 e vinda de uma família de posses e bastante leitora, foi educada por seu pai, juiz de direito, e por sua mãe. Com apenas 20 anos publicou seu primeiro livro, O quinze, em 1930. A obra fez tanto sucesso que à época se chegou a duvidar que tivesse sido escrita por uma mulher. Os escritores de então, por exemplo, a princípio atribuíram a autoria da obra a um homem que escrevia sob um pseudônimo feminino, tamanho o preconceito no que se referia a uma literatura escrita por mulheres.

Rachel colocou-se na vanguarda de sua época ao penetrar no mundo das letras, na redação dos jornais e na célula partidária, espaços entranhadamente masculinos. A estréia em livro, ocorrida em 1930, com o romance O quinze, que trata do drama dos flagelados e de agudas questões sociais, provocou tal impacto nos meios literários que houve até quem duvidasse de sua identidade (DUARTE, 2003, p. 164).

Tal espanto deu-se por conta, além da qualidade literária e do preconceito circulante no que tangia às mulheres, da própria história do romance, que trazia uma personagem feminina que exibia traços de emancipação e preferia viver sozinha do que aceitar um casamento tradicional, pensamento que contrariava todas as convenções da época. Essa caracteristica de delinear personagens femininas fortes é imperativa em todas as obras ficcionais de Rachel de Queiroz. Em seus livros, as mulheres têm destaque além do ambiente doméstico, o que faz com que sua literatura seja considerada pioneira.

A mesma situação pode ser vista na narrativa As três Marias, que consiste em um romance de formação sentimental sobre uma geração de mulheres que, em meio a uma educação rígida e conservadora, não tinham muitas opções de futuro. Cabia a elas optar por entre a vida religiosa e a vida matrimonial, escolha normalmente feita pela figura paterna da familia. Diante da impotência feminina ante as parcas opções de futuro que tinham perante si, entre o casamento e vida institucionalizada mediante, sobretudo, ao catolicismo, quem não tinha nem uma nem outra vocação acabava com uma vida desgarrada da sociedade. Logo, era como se, desde o seu nascimento, seu destino já estivesse traçado.

Essa sistemática é bastante clara no romance de Rachel de Queiroz, cuja história é contada em primeira pessoa sob a perspectiva de Maria Augusta, ou Guta - reconhecidamente a própria autora, já que se aponta que a obra é em certa medida autobiográfica. A menina é órfã de mãe, mas bem cuidada pela madrasta, com quem seu pai se casou depois de viúvo. O pai vive feliz com a nova esposa e tem filhos com ela, no entanto Guta não se sente parte dessa nova família e, com isso, a madrasta faz todos os esforços possiveis para mandá-la a um colégio interno, no qual poderia ter formação para, quando dali saísse, arranjar um bom marido, ou mesmo decidir-se pela vida religiosa.

As demais personagens centrais são: Maria da Glória, órfã de pai e mãe, que sonha com a realização pessoal pelo casamento, enquanto vive com naturalidade o luto paterno e materno; e Maria José, que se apega à religião a fim de lidar com os dramas familiares que vive. Sua familia é abandonada pelo pai quando a menina ainda é criança. Ele foi viver com outra mulher e deixou a esposa sozinha para sustentar os filhos pequenos.

As três amigas, Guta, Maria da Glória e Maria José, conhecem-se em um internato católico só para meninas e, por serem inseparáveis, recebem no colégio o apelido de as três Marias. Sua amizade prolonga-se, apesar de cada uma trilhar, quando adultas, um caminho pessoal e único.

Após o tempo em que passaram no internato, já tendo terminado os estudos, Maria da Glória casa-se com Afonso e tem um filho dele, constituindo uma familia sem defeitos, representando que a felicidade também é possivel de ser encontrada no casamento e na formação de uma familia. Já Maria José se torna uma mulher bastante religiosa e decide ir morar com a mãe e a irmã, passando a trabalhar como professora na cidade grande, Fortaleza. Por conta das suas atividades profissionais e do seu apego 
à religião, acaba afastando-se dos prazeres da vida, incluindo o casamento e relacionamentos amorosos. Faz da solidão a sua morada.

Por sua vez, Guta escreve para si um destino diferente, indicando certo inconformismo com as possibilidades que a vida tem a lhe oferecer. Ao deixar o colégio, retorna para casa e assume, por vontade da família, o papel de dona de casa - função social feminina no lar e no seio familiar -, dividindo as tarefas do lar com a madrasta. No entanto, como esse não era o seu desejo, vai trabalhar como datilógrafa em Fortaleza, passando a morar com Maria José. Na cidade conhece Raul, um boêmio artista plástico, por quem se apaixona. Tem um romance rápido com ele, que é casado e a queria como amante. Por esse motivo, termina com ele. Mais tarde, descobre que Aluísio, um amigo, estava gostando dela, mas dias depois o rapaz se suicida, e todos a culpam por isso. Abalada com a história, Guta vai passar férias no Rio de Janeiro e lá conhece Isaac, com quem tem sua primeira noite de amor. Sente-se culpada por isso, por conta do tabu que envolve a relação sexual fora do casamento. Descobre-se grávida do jovem e, com o fim das férias, acaba tendo de voltar a Fortaleza. Sofre um aborto, ou o provoca - o livro não deixa isso muito claro -, e decide voltar para o interior, para a sua familia, embora ao retornar para casa Guta declare: "Vou para o sertão, para casa. [...] Sinto-me cada vez mais triste, doente e só" (QUEIROZ, 2017. p. 193), demonstrando com isso sua infelicidade por não ter encontrado o seu caminho. Afinal, não descobriu uma saida que the satisfaria.

Felicidade e tristeza, atração pelo total, seja a morte, seja a luxúria, compõem uma mulher ao mesmo tempo incapaz de escapar às malhas da familia patriarcal, simbolizada pela volta de Guta para o sertão, e infeliz e incompleta por isto. Apesar de apresentar o limite imposto à mulher, portanto de ter consciência de um mecanismo social, ela não escapa ao seu poder. A demasia, o excesso, a hybris da mulher é desejar a plenitude e a liberdade. O castigo, parece, é a morte, a perda, a queda (SPERBER, 2017, p. 252).

A própria Guta reconhece que esse é o seu destino e o que deve fazer, conformando-se com o fato de que a vida que pretendia levar nunca daria certo, apesar de nunca ter ficado claro qual era o caminho que gostaria de ter seguido. A respeito do seu breve romance com Isaac, afirma:

Agora, cada um voltou ao seu meio, cada um se reintegra na sua paisagem, e se perde do outro mais completamente. [...] Tudo parecia realizado e completo. [...] E, afinal de contas, fora só um momento. E esse momento passou. Cada um voltou a ser o que era antes (QUEIROZ, 2017, p. 194).

Por essa razão, concorda-se com Sperber (2017) quando declara:

As mulheres passam por conflitos, exprimem anseios diferentes, podem ser de classes sociais diferentes, mas em última instância a mulher não se realiza fora do encaixe na sociedade patriarcal, simplesmente porque não se apresenta outro espaço e porque mesmo que exista enunciação, pela via dos romances, há palavras que não conseguem ser ditas (SPERBER, 2017, p. 246).

Assim, a mulher, sem encontrar seu espaço na sociedade, acaba tendo de limitar-se a certo padrão social, simplesmente para ser aceita e se enquadrar nessa sociedade, considerando que não pode fugir dela, preferindo o tolhimento à liberdade almejada à sua maneira e, por conseguinte, à solidão. "O maior problema tematizado não é a discriminação racial, mas a situação da mulher, tanto mais dificil quando não se adapta perfeitamente ao perfil previsto pela sociedade patriarcal" (SPERBER, 2017, p. 244).

Analisando o conceito da família patriarcal brasileira, chamam a atenção as interpretações feitas por autores como Gilberto Freyre e Antonio Candido de Mello e Souza dos espaços familiares do século XVI ao XIX. Ambos reforçam que nessa ponte entre o passado e o presente se construiu a formação social do Brasil. As suas obras colocam em cena principalmente um modelo cunhado pela análise da estrutura dos grupos dominantes que compunham a economia açucareira do Nordeste do Brasil, que resultaria em dois pares de oposição antagônicos, ou seja, um familiar, regido pelas normas da família patriarcal, e outro não familiar e, portanto, marginalizado. A presença das camadas senhoriais destacavase principalmente pela análise de um processo 
de homogeneização de práticas sociais que reforçavam os espaços de dominação masculina e a subordinação da mulher (CORRÊA, 1981).

É nesse ambiente das familias abastadas e com fortes laços com uma herança colonial que Raquel de Queiroz apresenta os estreitos limites dos resquícios materiais deixados pelas mulheres. A sensibilidade em torno dessas memórias deixa escapar um desabafo bem particular pelas restrições de um ciclo de vida que tinha como um dos seus clímaces o casamento e a maternidade, dificultando o acesso a uma cultura letrada. Ironicamente, a autora deixa pistas sobre um futuro que apresenta um prognóstico mais positivo possibilitado por uma significativa mudança cultural que, se não rompia totalmente com o passado, já tinha parte de suas restrições contestadas por algumas dessas mulheres.

Tenho tudo na memória, passei minha infância mexendo naquelas coisas com curiosidade e amor [...]. Uma caixa com as luvas e grinaldas do casamento. Um vidro vazio, a fivela de prata de um cinto, dois livros: um volume de Moreninha e as Meninas. Exemplares da condessa de Segur. Um caderno de modinhas, copiadas por ela, numa letra infantil, redonda e pesada. [...] Pobre mamãezinha, deve ter escrito tão pouco na vida! Talvez só aquele caderno de modinhas, e uma outra carta a namorado [...]. Não, agora me lembro de outra coisa escrita por sua mão: na mala há ainda um manual, um Adoremus Preto, com uma cruz dourada na capa. Na primeira página, mamãe escreveu: "No dia 13 de janeiro nasceu a minha filha Maria Augusta. É gordinha e morena e dizem que se parece com o pai e é melhor que se parecer comigo" (QUEIROZ, 2017, p. 30).

Ainda, Raquel de Queiroz levanta outras questões: o peso de uma estrutura social rígida que mantinha forte caráter de exclusão social. Assim, por exemplo, é o caso de Jandira, descrita como "filha natural, adulterina" de um pai casado e de uma mulher mestiça e humilde. Tal posição para autores como Celso Furtado (1959) é explicada por uma herança colonial que legou uma organização familiar estruturada pelos senhores de engenho e que diferenciava o Nordeste no tocante à estratificação social, uma vez que a rigidez social era maior ali que em outras regiões do Brasil. Seja como for, a pouca mobilidade social e a hierarquia pouco fluida que privilegiava uma estrutura social da classe dominante branca não deixavam de atingir as mulheres, principalmente as mestiças. Essa realidade de maior exclusão no caso das mulheres que não se enquadravam no modelo da familia patriarcal aparecia de maneira especial nas frases como "conheça o seu lugar, minha filha", ou quando a narrativa aponta a violência que se mantinha forte pela pouca transformação da realidade brasileira após mais de quatro séculos de história de exclusão.

\begin{abstract}
A vida se mostra, à sua frente, bela, sedutora iluminada. Mas, para você é apenas uma vitrina: não estenda a mão, que bate no vidro; e não despedace o vidro; você sairá sangrando... Contente-se em olhar, pode "até desejar, se quiser". Mas fique nisso. Vá para o colégio: estude com as outras, vista o que elas vestem, ria com elas, brinque com elas. Afine o seu coração pelo delas, e, se quiser, aprenda o que é o amor. leia os livros e sonhe! Mas, quando chegar a sua hora, recue, deixe o estudante sentimental que the faz serenatas, não se atreva a pensar no menino de familia, e procure um de sua igualha. Nunca esqueça, porque ninguém lhe permitirá jamais esquecer, a sua marca original, o ventre manchado que a gerou, o dia escuro que a viu nascer (QUEIROZ, 2017, p. 30).
\end{abstract}

No que concerne à literatura em si, Rachel de Queiroz surpreende ao posicionar somente mulheres no centro de seus romances, desenvolvendo personagens bastante progressistas e que, de uma forma ou de outra, desafiavam os padrões impostos pela sociedade. No livro As três Marias, por exemplo, obra discutida neste artigo, todas as figuras masculinas que surgem ficam relegadas a segundo plano, em uma tentativa de demonstrar que as mulheres devem ter em suas mãos o poder de escolher seu próprio destino, semeando já no começo do século XX a emancipação feminina.

Seguindo a mesma linha de Rachel de Queiroz, discutindo em seus livros questões pertinentes ao universo feminino, como a liberdade e a necessidade de a mulher ter o direito de decidir sobre o seu futuro, temos outra figura emblemática no cenário literário: Lygia Fagundes Telles, considerada a dama da literatura brasileira. Em 1938, deu-se sua primeira publicação, o livro de contos Porão e sobrado - oito anos depois da estreia literária de Rachel de Queiroz. 
Nascida em 1923, pode-se dizer que Lygia Fagundes Telles é da mesma geração de Rachel de Queiroz, contudo ambas vivenciaram experiências muito diferentes, sobretudo por conta do contexto de cada uma. Enquanto Queiroz viveu a realidade da Região Nordeste, com questões como a seca e o regionalismo nordestino muito peculiar ${ }^{3}$, Telles nasceu na capital São Paulo, passando parte de sua infância no interior paulista. Seu pai, assim como o de Rachel, também era advogado e exerceu enorme influência na carreira futura da filha, que viria a se formar posteriormente em Direito.

Lygia começou a escrever muito cedo, incentivada por nomes conhecidos do cenário literário, como Carlos Drummond de Andrade e Érico Verissimo (TELLES, 2019). Rachel também ingressou na literatura bastante cedo e sofreu boas interferências em termos culturais, já que seus pais tinham relações próximas com intelectuais da época, fazendo com que estes frequentassem constantemente sua casa (QUEIROZ, 2017).

Trabalhando como procuradora do Instituto de Previdência do Estado de São Paulo, exercendo seu cargo até a aposentadoria, Lygia intercalava seu trabalho com a literatura, embora seu sucesso no meio editorial tenha sido bastante grande desde praticamente o início de sua carreira como escritora.

Ao comparar a vida das duas autoras discutidas aqui, verificam-se muitas semelhanças. Há semelhanças também em seus trabalhos, principalmente no que concerne aos textos tratados neste artigo. Ambos, por exemplo, flertam com fatos reais. Enquanto As três Marias descreve fatos biográficos da vida de sua autora e da amizade que ela formou no colégio interno e manteve até o fim de sua vida, As meninas foi originalmente publicado em 1973 e tem como pano de fundo o contexto político-social envolvendo a ditadura civil-militar, período em meio do qual o livro foi lançado.

No posfácio da edição de 2009 de As meninas, Cristóvão Tezza (2009) explica que o livro de Lygia veio em uma época conturbada para o Brasil. Por conta do golpe de Estado de $1964^{4}$ e da emissão do Ato Institucional n. ${ }^{0} 5(\mathrm{Al}-5)^{5}$, o país sofria forte repressão, além de grande pressão social e moral, afastando-se mais e mais da liberdade, sobressaindo, em contrapartida, o abuso de poder das autoridades.

Nesse contexto, valores individuais burgueses infiltravam-se no mecanismo social. Traçando um panorama bastante consciente da época, afirma Tezza (2009, p. 286):

\begin{abstract}
Nesse Brasil jurássico, divórcio ainda se chamava "desquite" - e condenava a vitima mulher, só ela, à desgraça social perene -, a virgindade era ainda um valor mitológico que valia uma guerra pessoal, homossexuais chamavam-se "bichas" e era preciso decidir o que fazer com eles e o que dizer sobre eles, o racismo ainda se mantinha como uma atitude perfeitamente verbalizável no dia a dia, sem consequências, a familia tradicional permanecia um valor moral, social e econômico poderoso e intocável, a cultura letrada circulava no máximo por um quinto da população, privilégio das classes médias urbanas, e, por último, o mundo católico definia-se praticamente como a única referência religiosa com peso politico na vida brasileira.
\end{abstract}

As meninas passa-se em apenas dois dias, em meio à ditadura civil-militar e a uma greve da faculdade em que as meninas estudam, e é ambientada na cidade de São Paulo. Sabe-se, pelas indicações históricas apontadas ao longo da história, que o romance ocorre no ano de 1969, em função da referência indireta ao sequestro do embaixador norte-americano Charles Elbrick ${ }^{6}$, que resultou na liberação de 15 presos políticos brasileiros.

\footnotetext{
3 É interessante notar que o Nordeste vinha progressivamente perdendo espaço na economia brasileira, contrastando com o crescimento contínuo e vertiginoso do Sudeste (FURTADO, 1982, p. 198).

4 O processo intervencionista de 1964 colocaria fim ao governo constitucional de João Goulart, iniciando assim um período de governo militar que entrou pelos anos 1980. Interessa notar que os anos de 1860-70 seriam marcados por golpes de Estado militares em diversos paises da América Latina, ou seja, dois terços da população latino-americana que vivia em Estados sob dominação castrense (BORGES, 2007) 5 Datado de 13 de dezembro de 1968, o Ato Institucional n. 5 fechou o Congresso Nacional, suspendeu "a concessão de habeas corpus e as franquias constitucionais de liberdade de expressão e reunião, permitiu demissões sumárias, cassações de mandatos e de direitos de cidadania, e determinava que o julgamento de crimes políticos fosse realizado por tribunais militares, sem direito a recurso" (SCHWARCZ; STARLING, 2015, p. 441).

6 Como aclaram Lília Schwarcz e Heloisa Starling (2015, p. 441), essa seria a "mais espetacular ação executada pela esquerda revolucionária no Rio de Janeiro, em 1969, e surgiu na cabeça de dois jovens militantes - Franklin Martins e Cid Benjamin - da Dissidência Universitária da Guanabara, uma organização minúscula mas atrevida: o sequestro do embaixador norte-americano, Charles Burke Elbrick, que só seria solto em troca da libertação de quinze presos políticos. Era um tipo de ação inesperada e de largo alcance: buscava a repercussão aberta, transformava a luta armada, a tortura e a existência de presos políticos no país em notícia internacional - fato que os militares negavam reiteradamente -, e desmoralizava a ditadura".
} 
A história descreve as transformações pelas quais passam três jovens universitárias, de origens e classes sociais distintas, que se conhecem no pensionato de freiras católicas Nossa Senhora de Fátima, onde vivem. São elas: Lorena Vaz Leme, intelectual de familia paulista tradicional, abastada e proprietária de terras, que mantém um romance com um homem casado, mas permanece virgem - demonstrando com isso o valor da virgindade antes do casamento; Lia de Melo Schultz, chamada de Lião pelas amigas, filha de baiana com alemão e militante na luta contra a ditadura, gravitando em torno de um grupo de esquerda armada e que tenta tirar da prisão o namorado, preso político; e Ana Clara Conceição, que usa sua beleza para conseguir casar-se com o noivo burguês e, consequentemente, ascender socialmente, porém envolve-se com drogas e tem como amante um traficante.

São contadas na obra três histórias diferentes, mas elas entrelaçam-se a todo o momento, embora cada personagem apareça bem desenvolvida individualmente na trama e tenha cada um o seu desfecho. No decorrer da narrativa, são revelados variados aspectos de uma época político-social conturbada e contraditória:

E estamos morrendo. Dessa ou de outra maneira não estamos morrendo? Nunca o povo esteve tão longe de nós, não quer nem saber. E se souber ainda fica com raiva, o povo tem medo, ah! como o povo tem medo. A burguesia ai toda esplendorosa. Nunca os ricos foram tão ricos, podem fazer casas com as maçanetas de ouro, não só os talheres mas as maçanetas das portas. As torneiras dos banheiros. Tudo de puro ouro como o gângster grego ensinou na sua ilha. Intactos. Assistindo da janela e achando graça. Resta a massa dos delinquentes urbanos. Dos neuróticos urbanos. E a meia dúzia de intelectuais. Os simpáticos simpatizantes. Não sei explicar mas tenho mais nojo de intelectual do que de tira. Esse ao menos não usa máscara (TELLES, 2009, p. 19-20).

A estudante de Direito Lorena, por sua melhor condição financeira e por ter uma vida mais estável, além de ter a mãe por perto, acaba servindo de ajuda econômica às amigas e também funciona como uma espécie de psicóloga, aconselhando as meninas e dando suporte a elas. Orbita, por essas características e por funcionar como mais ou menos a líder do grupo, no protagonismo da obra, embora não seja possivel afirmar com clareza se de fato ela é mesmo a personagem central da obra, ou se esta tenha mesmo um único pilar. Muito romântica, Lorena guarda-se para um médico mais velho e casado, Marcus Nemesius, ou M. N. Passa a história inteira esperando por um telefonema dele, que nunca chega. A narrativa deixa dúvidas sobre a posição de Lorena diante do contexto em que as meninas estavam vivenciando, por causa de sua posição social. Ao mesmo tempo que apoiava as amigas nas suas lutas contra o sistema, mantinha-se presa a ele, em um jogo dúbio:

- Nome, por favor.

- Lorena Vaz Leme.

- Universitária?

- Universitária. Direito.

- Pertence a algum grupo político?

- Não.

- Por acaso faz parte de algum desses movimentos de libertação da mulher?

- Também não. Só penso na minha condição.

- Trata-se então de uma jovem alienada?

- Por favor, não me julgue, só me entreviste. Não sei mentir, estaria mentido se dissesse que me preocupo com as mulheres em geral, me preocupo só comigo, estou apaixonada. Ele é casado, velho, milhares de filhos. Completamente apaixonada.

- Uma pergunta indiscreta, posso? Vocêé virgem?

- Virgem. [...]

- Quer dizer que não são amantes. Será ousadia minha perguntar o motivo?

- Ele não quer. Nem me procura mais, faz um montão de dias que nem me telefona. [...] Piorou muito depois que entrou num cursilho.

- Entrou num cursilho? Se entrou é porque está a fim de salvar o casamento. Você não vai ter nem amante nem marido.

- Mas quem é que quer casar?

- Você. Quer casar sim senhora, não pensa noutro assunto, certo? (TELLES, 2009, p. 160161, grifo do autor).

Já Lia estuda Ciências Sociais e é envolvida no movimento político universitário que luta contra a ditadura. Tem um namorado preso político que é enviado ao exílio na Argélia, país para o 
qual ela também vai, a fim de acompanhar o rapaz, mesmo precisando se desfazer de sua própria vida e familia para isso. De fato, ela nem cogita a possibilidade de não fugir com ele, já que entende que sua postura mais correta é acompanhar o namorado, independentemente de suas condições ou desejos.

Ana Clara, por sua vez, é estudante de Psicologia, mas trancou o curso. Sofreu maustratos no passado, quando vivia com a mãe em canteiros de obras. Ao longo da narrativa, sonha com um noivo rico e conservador, que the proporcionaria uma vida entendida como normal, apesar de não se saber se esse noivo existe mesmo, ou se é apenas sua imaginação. No entanto a jovem envolve-se com um traficante de drogas, do qual vira amante: "Mas com o noivo é tudo platônico, grávida do Max, o outro. Tem que fazer depressa o aborto e depois a plástica [himenoplastia] na zona sul" (TELLES, 2009, p. 166). Em razão de seu vício em drogas, acaba sofrendo overdose ao final do livro.

Constata-se ao longo da história que o destino é sempre uma escolha individual, não importam as circunstâncias, no entanto o caminho de todas as personagens perpassa necessariamente pela esfera masculina. Logo, é sempre o homem, mesmo em sua ausência, que define o futuro das meninas. Pode-se observar esse mesmo aspecto nas três linhas narrativas. Esse aspecto também fica bastante evidente no livro de Rachel de Queiroz, apesar de sua história se passar em outra região do pais, verificando que o patriarcalismo suscita influência independentemente de localização geográfica.

Assim, por mais que as meninas tenham consciência das amarras sociais, acabam não conseguindo se desvencilhar delas, fracassando nas tentativas de libertação das imposições sociais, tal qual aconteceu com Guta em As três Marias. Lia e Lorena, por exemplo, fogem da responsabilidade concreta de encarar suas próprias vidas, depositando em mãos alheias seu futuro, presas ainda no império da convenção e das aparências sociais. A própria Lorena dá-se conta disso:

Sugere a máscara e tenho horror de máscara. Queria apenas ser verdadeira. Honesta. "O mundo do burguês é o mundo das aparências", Lião repetiu não sei quantas vezes. Eu e M. N. pertencemos à burguesia, logo, estamos condenados a esse mundo. Mas estamos mesmo? Queria ser mas vou estar na engrenagem do faz de conta" (TELLES, 2009, p. 195).

Enquanto isso, Ana Clara é a única que não se encaixa em nada e que de fato se entrega aos prazeres do sexo e das drogas, situação da qualé uma vitima simbólica, em um presságio moralizante, ao vir a falecer por conta de uma overdose:

A senhora me desculpe, Madre Alix, mas Ana
é o produto desta nossa bela sociedade, tem
milhares de Anas por aí, algumas aguentando a
curtição. Outras se despedaçando. As intenções
de socorro e etecetera são as melhores do mun-
do, não é o inferno que está exorbitando de boas
intenções, é esta cidade (TELLES, 2009, p. 146).

No posfácio da edição de 2009 de As meninas, Cristóvão Tezza (2009) relembra que uma vez Lygia disse que a função do escritor é ser testemunha do seu tempo e da sua sociedade. Deve ser por esse motivo que as conversas e os pensamentos que aparecem ao longo do livro entre as meninas reproduzam os costumes e assuntos que fervilhavam na década de 1970, tais quais a liberação sexual da mulher e suas fronteiras, a radicalização política, as experiências com alucinógenos e a luta em defesa da liberdade - conflitos do período da ditadura civil-militar por parte de uma juventude que queria se soltar das amarras sociais, mas que ainda precisava manterse de alguma forma presa a essas convenções, nem que fosse para agradar à familia: "Sou capaz de mandar de lá uma foto com vestido de noiva pra efeito familiar, obrigo Miguel a posar de noivo, ô! o sucesso da foto no porta-retrato de prata da sala de visitas" (TELLES, 2009, p. 141).

No que se refere à narração, Rachel de Queiroz prefere manter no que se refere à obra analisada aqui uma estrutura narrativa cronológica, marcada pela causalidade. A estrutura da obra é bastante clara e lógica; narra fatos do passado usando o tempo verbal passado, e os fatos do presente por intermédio de verbos também no presente. A escritora não inova nessa questão, fazendo com que sua obra seja muito linear e o leitor a apreenda facilmente. 
Por sua vez, o estilo de Lygia é muito diferente. Sua narração descreve a ação e o pensamento no momento em que ambos ocorrem, surgindo muitas vezes na mesma frase simultaneamente relances do que certa personagem pensa e da ação que acontece. Assim sendo, o tempo verbal sempre está no presente, apesar de também serem relatados fatos do passado, e a perspectiva de passado é sempre dada por esse instante e pela percepção da personagem enquanto age.

É interessante observar que, na mescla entre pensamento e ação, ainda se vê também a alternância de vozes ao longo da obra. Ora a narrativa se desenvolve sob o olhar intimo e intrasferivel de cada uma das personagens - Ana Clara, Lorena e Lia -, ora é relatada por meio do narrador, ou seja, a terceira pessoa gramatical, que eventualmente costura as passagens e que funciona como um narrador-observador, por não ter conhecimento do que se passa na mente das meninas. Com essa atitude, têm-se a todo o momento fragmentos de histórias, os quais são limitados social, histórica e tematicamente pelos olhares narrativos. Cabe ao leitor dessa maneira ajustar todos esses fragmentos e dar unidade à obra, organizando a narrativa e encaixando os vários episódios contados, com base em seus valores e conceitos.

Ter mulheres atuando na literatura faz-se de extrema importância, principalmente em uma sociedade que, embora já não tão reprimida como outrora, ainda preserva ares de conservadorismo e o patriarcalismo ainda se faz muito presente, sobretudo nas regiões mais interioranas do pais. Sobre isso comentam Peregrino e Pereira (2012, p. 160): "Além de explicitar suas escolhas ideológicas, uma mulher que exerce a atividade da literatura traz sua condição feminina como caracteristica especifica".

Há vários autores homens que discutem a função social da mulher e dão voz a ela, e fazem isso muito bem, mas ninguém melhor do que a própria mulher para discutir as mazelas por que passa ao longo de sua trajetória de vida. Como bem diz Lygia Fagundes Telles (2009, p. 298) sobre o seu ofício de escritora, "uns lutam com o cimento armado. Com as leis. Outros, com os bisturis. Com as máquinas - tantas e tão variadas lutas. Eu luto com a palavra. É bom? É ruim? Não interessa, é minha vocação".

\section{Considerações finais}

Constata-se ainda hoje no mercado editorial e, por conseguinte, nas prateleiras das livrarias a grande quantidade de livros escritos por homens, sobretudo brancos e originários do Rio de Janeiro ou de São Paulo, ficando menos evidente ao grande público a literatura escrita pelas chamadas minorias. Destaca-se entre essas minorias a literatura feita por mulheres, as quais tradicionalmente sempre estiveram atrás dos homens no que se refere a oportunidades na esfera literária. Antigamente, porém, era ainda mais dificil à mulher ingressar no mercado editorial, tendo em vista todas as questões culturais que a limitavam.

Apesar disso, no começo do século XX surgiu na literatura brasileira Rachel de Queiroz, trazendo nos seus livros protagonistas mulheres, mostrando a importância de se discutir assuntos que envolvem o universo feminino. Um pouco mais tarde, Lygia Fagundes Telles também despontou no panorama literário, em meio a uma época bastante conturbada do cenário nacional: a ditadura civilmilitar. Seus livros discutiam basicamente a postura das mulheres perante o contexto político-social, algo impensável até pouco tempo antes de seu aparecimento na literatura.

Logo, essas duas escritoras são referência para qualquer estudo que abranja literatura escrita por mulheres, tamanho o pioneirismo e a ousadia, se assim se pode dizer, de escrever livros cujos temas giravam em torno da emancipação feminina, em uma época em que a mulher mal tinha acesso a determinados direitos.

Os dois livros tratados neste artigo - As três Marias, de Rachel de Queiroz, e As meninas, de Lygia Fagundes Telles - traçam um painel das vivências de três jovens em busca de si mesmas, em contextos e épocas diferentes, lutando de certa forma em defesa da sua própria liberdade. Verifica-se com grande destaque em ambas as obras que, quando a mulher não vê opções de vida fora daquelas já convencionalmente aceitas - basicamente, o casamento e a religião -, cabe a ela aceitar a ordem 
instituída e o seu papel nesse sistema, ou aceitar as punições da comunidade e de si própria.

Pertencentes a uma geração de intelectuais brasileiros que lidaram com as mudanças que marcaram o século XX, as duas autoras inverteram a imagem de protagonistas da história comumente dada aos homens. Por outro lado, conseguiram retratar de forma crítica as angústias e os caminhos muitas vezes demarcados pelas especificidades de uma sociedade patriarcal brasileira que obstaculizava as alternativas que fugiam dos padrões impostos pela familia tradicional. Contemplar essas narrativas sobre as mulheres que se unificam por um protagonismo marcado pela desigualdade de gênero permite entender a formação de uma sociedade que impacta pela relação indissolúvel entre cultura, violência e resistência crescente nos espaços femininos.

Mais uma vez, as imagens que as memórias das mulheres vão tecendo têm sido matizadas por tons que exprimem relação de dependência, comunhão e resistência aos padrões constantemente reforçados pela familia patriarcal. Tanto as visões idilicas sobre as mulheres que atingem o seu auge no papel maternal como a marginalização das resistências consideradas como perdição, em maior ou menor escala, criam uma ambiguidade entre a liberdade e o sentimento de pertença à identidade cultural fruto de uma sociedade patriarcal que perpassa a narrativa de ambas as autoras. O que queremos pontuar aqui é que, como no reflexo de um espelho, a interpretação da realidade brasileira pela visão feminina deixa mais visivel uma estrutura ainda forte de violência e subjugação, mas, igualmente, marcada por insurreição. Ou seja, "as filhas dos homens", que não podiam ser anjos - como recupera Raquel de Queiroz (2017, p. 93) das escrituras -, buscavam se contar e recriar por meio das especificidades de uma realidade patriarcal que não foi construida para refletir as imagens tais como são escritas por elas.

A prosa fácil e sedutora deixar entrever, no entanto, a realidade das rodas cultas e mais abastadas da sociedade brasileira, mas que por vezes soava dissonante da realidade das mulheres da classe trabalhadora brasileira. Importante lembrar, portanto, que Rachel de Queiroz vinha de uma familia tradicional e abastada do Nordeste brasileiro e, ao contrário da grande massa feminina a que foi contemporânea, recebeu educação privilegiada (PEREGRINO; PEREIRA, 2012), assim como Lygia Fagundes Telles. Além disso, as duas circulavam em espaços de prestígio e tinham vínculos com intelectuais e pessoas influentes da época, que as ajudaram a alcançar o sucesso por meio da sua literatura. De qualquer forma, é notório o mérito das autoras em relação principalmente ao seu pioneirismo no que concerne à literatura engajada em prol das mulheres, tão subestimada ainda hoje, no século XXI.

Talvez não seja exagero dizer que Rachel de Queiroz em suas obras militava pela emancipação feminina. Com seus livros, chamou as mulheres do Brasil a conhecerem outros caminhos, além do casamento e da vida religiosa. O mesmo fez Lygia Fagundes Telles. Cada uma à sua maneira e usando o contexto que lhe era mais conhecido, o Nordeste e o Sudeste, mas ambas em prol do que chamamos no século XXI de empoderamento feminino, algo ainda muito almejado e que demanda batalhas para se alcançar em sua plenitude.

\section{Referências}

ADICHIE, Chimamanda Ngozi. Sejamos todos feministas. São Paulo: Companhia das Letras, 2014. https:// doi.org/10.14393/cef-v31n1-2018-19

BORGES, Nilson. A doutrina de segurança nacional e os governos militares. In: FERREIRA, Jorge; DELGADO, Lucilia de Almeida Neves (org.). O Brasil republicano: o tempo da ditadura - regime militar e movimentos sociais em fins do século XX. Rio de Janeiro: Civilização Brasileira, 2007. p. 13-42. https:// doi.org/10.14195/0870-4147_37_21

CORRÊA, Mariza. Repensando a familia patriarcal brasileira: notas para o estudo das formas de organização familiar do Brasil. Cadernos de Pesquisa, São Paulo, v. 37, p. 5-16, maio 1981.

COSTA, Isabel. Mais de 70\% dos livros publicados por grandes editoras brasileiras entre 1965 e 2014 foram escritos por homens. O Povo Online, 30 nov. 2017. Disponivel em: http://blogs.opovo.com.br/ leiturasdabel/2017/11/30/homens-e-brancos-tem-maior-fatia-no-mercado-editorial-desde-1965/. Acesso em: 22 jun. 2019. 
DEL PRIORE, Mary. A mulher na história do Brasil. São Paulo: Contexto, 1994.

DUARTE, Constância Lima. Feminismo e literatura no Brasil. Estudos Avançados, São Paulo, v. 17, n. 49, p. 151-172, 2003. Disponivel em: http://www.scielo.br/ pdf/ea/v17n49/18402.pdf. Acesso em: 22 jun. 2019. https://doi.org/10.1590/s0103-40142003000300010

FURTADO, Celso. Formação econômica do Brasil. Rio de Janeiro: Fundo de Cultura, 1959. https://doi. org/10.1017/s0022050700104267

FURTADO, Celso. Formação econômica do Brasil. São Paulo: Companhia Editora Nacional, 1982.

HARDMAN, Francisco Foot. Visões errantes: representações do trabalho urbano-industrial nordestino no século XIX. Ciências Sociais Hoje, São Paulo, p. 64-80, 1988.

PEREGRINO, Miriane da Costa; PEREIRA, Victor Hugo Adler. A (im)pertinente: questões de gênero e engajamento na literatura de Rachel de Queiroz. Miselânea, Assis, v. 11, p. 153-176, jan./jun. 2012. Disponivel em: http://seer.assis.unesp.br/index.php/miscelanea/article/view/641/607. Acesso em: 1. ${ }^{\circ}$ jul. 2019

PERROT, Michelle. As mulheres ou os silêncios da história. São Paulo: Edusc, 2005.

PERROT. Minha história das mulheres. São Paulo: Contexto, 2007.

QUEIROZ, Rachel de. As três Marias. Rio de Janeiro: José Olympio, 2017

SCHWARCZ, Lilia Moritz; STARLING, Heloisa Murgel. Brasil: uma biografia. São Paulo: Companhia das Letras, 2015. https://doi.org/10.18223/hiscult.v6i2.1946

SPERBER, Suzi Frankl. Personagens femininas de Rachel de Queiroz: exclusão ou inclusão na ordem patriarcal? Se correr o bicho pega, se ficar o bicho come. In: SILVA, Natali Fabiana Costa e et al. (org.). Mulheres e a literatura brasileira. Macapá: Editora da Unifap, 2017. p. 241-264. https://doi.org/10.17771/ pucrio.acad.4211

TELLES, Lygia Fagundes. As meninas. São Paulo: Companhia das Letras, 2009.

TEZZA, Cristóvão. As meninas: os impasses da memória - posfácio. In: TELLES, Lygia Fagundes. As meninas São Paulo: Companhia das Letras, 2009. p. 285-293.

\section{Endereço para correspondência}

Marilia Garcia Boldorini

Universidade da Região de Joinville

Rua Paulo Malschitzki, s/n

Bom Retiro, 892189-710

Joinville, SC, Brasil

Roberta Barros Meira

Universidade da Região de Joinville

Rua Paulo Malschitzki, s/n

Bom Retiro, 892189-710

Joinville, SC, Brasil

\section{Marília Garcia Boldorini}

Mestre pelo Programa de Pós-Graduação em Patrimônio Cultural e Sociedade, Universidade da Região de Joinville.

\section{Roberta Barros Meira}

Doutora em História Econômica pela Universidade de São Paulo. Docente do Mestrado em Patrimônio Cultural e Sociedade e do Departamento de História da Universidade da Região de Joinville - Univille. 